\title{
PRELIMINARY RESULTS OF GROUNDWATER RECHARGE EXPERIMENTS IN LARISA PREFECTURE
}

\author{
Soulios G. ${ }^{1}$, Voudouris K. ${ }^{1}$, Kalfountzos D. ${ }^{2}$, Kaklis T. ${ }^{1}$, Sotiriadis M. ${ }^{1}$, \\ Alexiou $\mathbf{J}^{2}$, and Kotsopoulos S. ${ }^{2}$ \\ ${ }^{1}$ Lab. of Engineering Geology \& Hydrogeology, Dept. of Geology, Aristotle University, 54124, \\ Thessaloniki,Greece.E-mail: gsoulios@geo.auth.gr,kvoudour@geo.auth.gr \\ ${ }^{2}$ National Agricultural Research Foundation, 41335 Larisa, Greece, kalfountzos@nagref.gr
}

\begin{abstract}
Thessaly is the most important agricultural region in Greece and their economic development is influenced by the availability of water resources. During the last decades the overexploitation has lowered the groundwater level. The paper presents the results of artificial recharge in the aquifer system of Larisa prefecture through injection borehole and trench. The experiments took place during the period MarchApril 2006. The field experiments provided useful guidance on the planning of pilot tests, data monitoring and analysis, which can also be applied to other regions with similar hydrogeological conditions. Finally, this work confirms that groundwater recharge using the wintertime torrential flows is an environmentally acceptable solution, as part of an integrated water resources management strategy.
\end{abstract}

Key words: Groundwater recharge, field experiment, Thessaly.

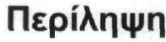

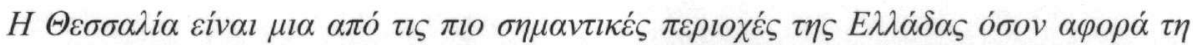

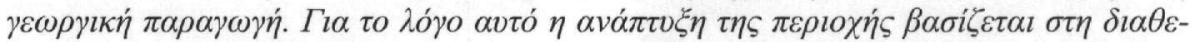

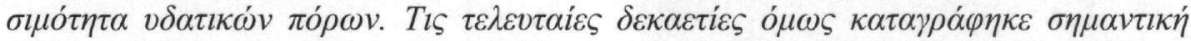

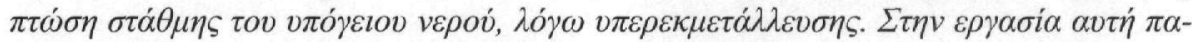

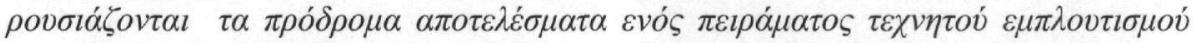

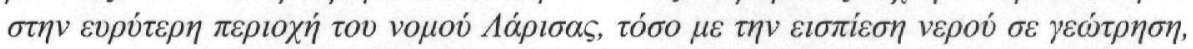

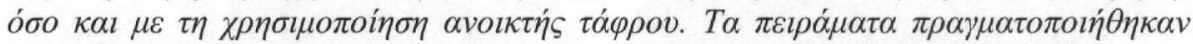

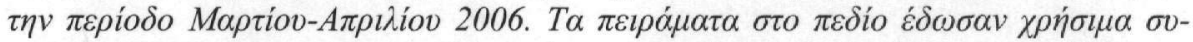

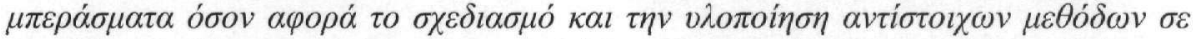

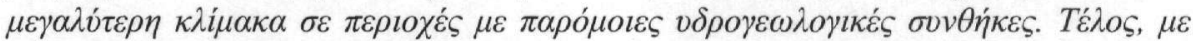

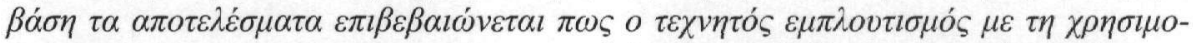

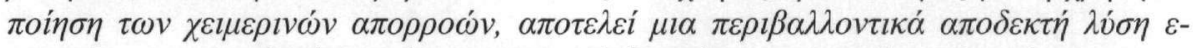

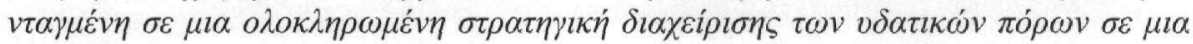
$\pi \varepsilon \rho i o \chi \dot{\eta}$.

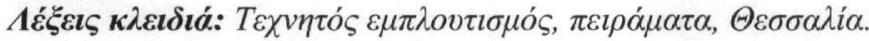




\section{Introduction}

Thessaly is dependent on groundwater resources for its water supply. It is the most important agricultural region in Greece. The land in the northeastern part of Thessaly is mainly used for the cultivation of cotton, cereals, tomatoes (Fig. 1). The mean annual rainfall of the area is $413 \mathrm{~mm}$ (station Larisa, period 1960-2005) and the average annual temperature is $15.1{ }^{\circ} \mathrm{C}$ (station Larisa, period 1970-2005). The area is characterized by unhomogeneous distribution of rainfalls and water resources. Water requirements for agricultural are high during the dry period (April-October) when the water availability is low.

The economic development of this area is influenced by the availability of water resources. The main source of irrigation water supply in northeastern part of Thessaly is groundwater, occurring in Quaternary deposits. The intense and extensive cultivation has led to a remarkable water demand increase, which is covered by the overexploitation of groundwater resources. In the last decades, groundwater extraction for irrigation use, has caused a significant decline in the piezometric level. Conservation of surface runoff is considered important to improve the groundwater potential and to offset the adverse effects of groundwater mining, which have taken place in many parts of Thessaly.

The artificial recharge of the aquifers could present an attractive solution to some problems, e.g. quantity and quality of groundwater (Buchn 1964, Bize et al. 1992, Bouwer 1996, Giao et al. 1998). Based on previous studies, it is concluded that groundwater recharge is an environmentally acceptable solution, as part of an integrated water resources plan, in order to improve the quality and quantity of groundwater (Peters 1985, Hionidi et al. 2001, Murray et al. 2002). Experimental investigations on artificial groundwater recharge via deep boreholes in Greece were undertaken by Fleet et al. (1995), Vafiadis et al. (1996), Koumantakis et al. (1999), Diamantis et al. (1999), Poulovasilis et al. (2002), Stavropoulos et al. (2005), Voudouris et al. (2006). The results showed that the injected fresh water stored in the aquifer could be recovered in the dry period when the water availability is low (Soulios 2004).

This paper deals with the results of groundwater recharge field experiments in northeastern part of Thessaly, prefecture of Larissa, via borehole and trench, during 2006. Firstly, the results of the hydrogeological study, including development of aquifers, water level measurements, hydraulic parameters and groundwater quality are presented.

\section{Geological and Hydrogeological settings}

\subsection{Geology}

The Chalki - Platykampos area in the prefecture of Larisa is a lowland area which is covered by quaternary deposits. The study area is covered by a geological map at a scale of 1:50,000; this map was surveyed by the Institute of Geological and Mineral Researches (IGME, Katsikatsos, Vidakis, Migiros, 1981). According to this map, in a range of 10-15 km away from the study area (Fig.1) there is no surface presence of other geological formations, but only alluvial and Plio-Pleistocene fluvial deposits.

In the southern part of Chalki, close to the Larisa- Athens National Highway a geological formation outcrops, which consists of mica schist, gneiss schist with layers of white, Jurassic age, marbles. This formation constitutes a part of early upper Cretaceous nappe which is visible in the north-eastern part of the study area, close to the Ossa Mountain. This nappe seems to be the bedrock of the study area.

The stratigraphic sequence of this area consists of:

- Early upper Cretaceous nappe

- Plio-Pleistocene fluvial deposits 
- Quaternary deposits, as we can see in the geological profile of borehole B1 (Fig. 2) including:

- Terrestrial deposits historic years

- Lacustrine deposits; the Lake Karla covered in the past bigger area than during the

- Deeper terrestrial deposits with transition characteristics probably to the PlioPleistocene fluvial formations.

Based on drilling data of the injection borehole (Fig. 2) the Quaternary deposits of the study area consist of alternations fine and coarse grain size materials.

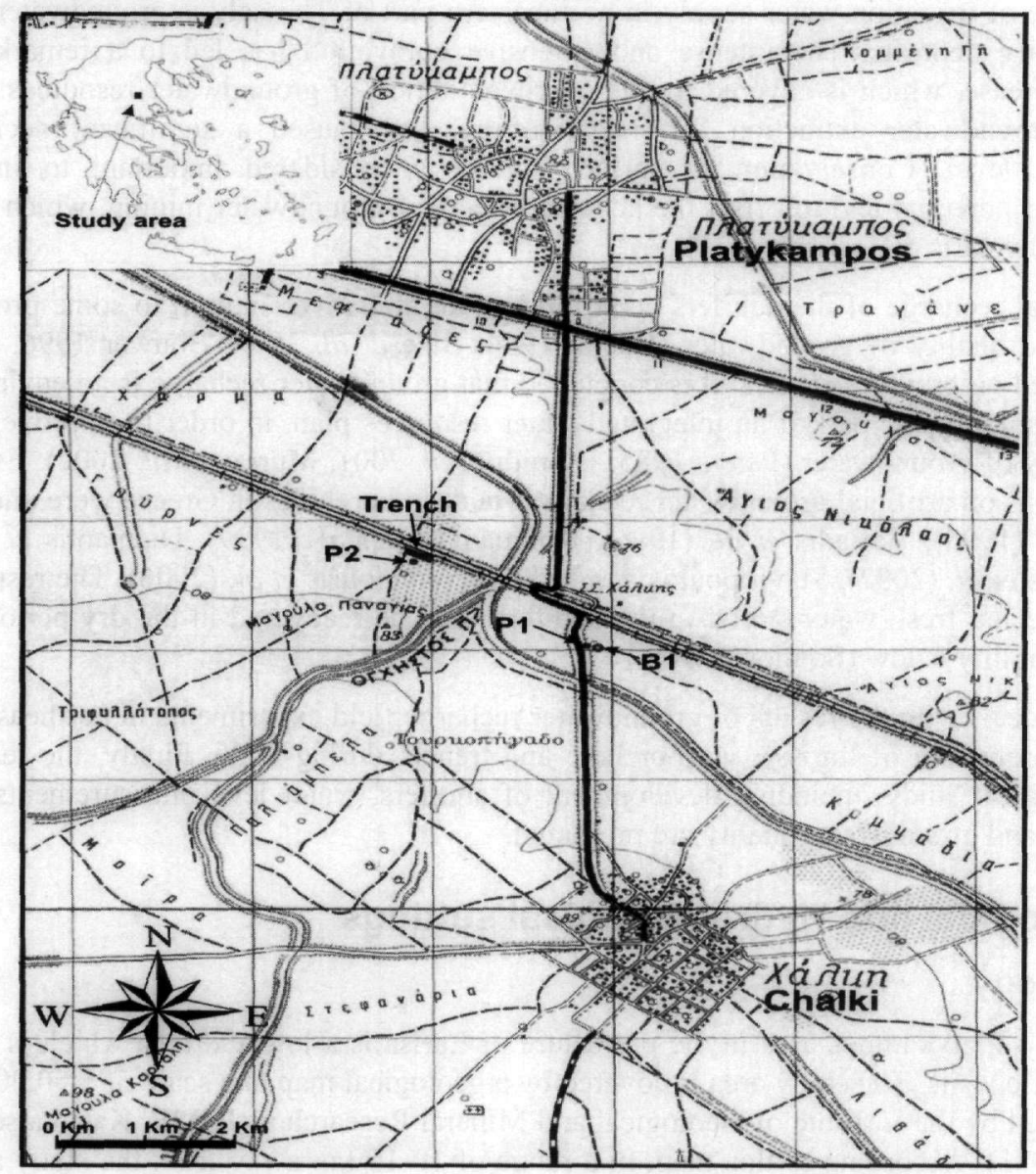

Figure 1 - Topographic map of the study area

\subsection{Hydrogeology}

The terrestrial facies of the Quaternary deposits form a multiple aquifer system, which is at least $400 \mathrm{~m}$ thick. This aquifer system is the main source that covers the water demands, by numerous deep boreholes.

The water level within these deposits was at an average depth of about 20-30 m below ground surface (b.g.s.) in the northern part, whereas in the south western part 140-170 m b.g.s.

The hydrograph of one representative borehole, drilled in alluvial aquifer of the study area is presented in Figure 3, showing the decline of the groundwater level $(\sim 50 \mathrm{~m})$ during 1972-2003. 


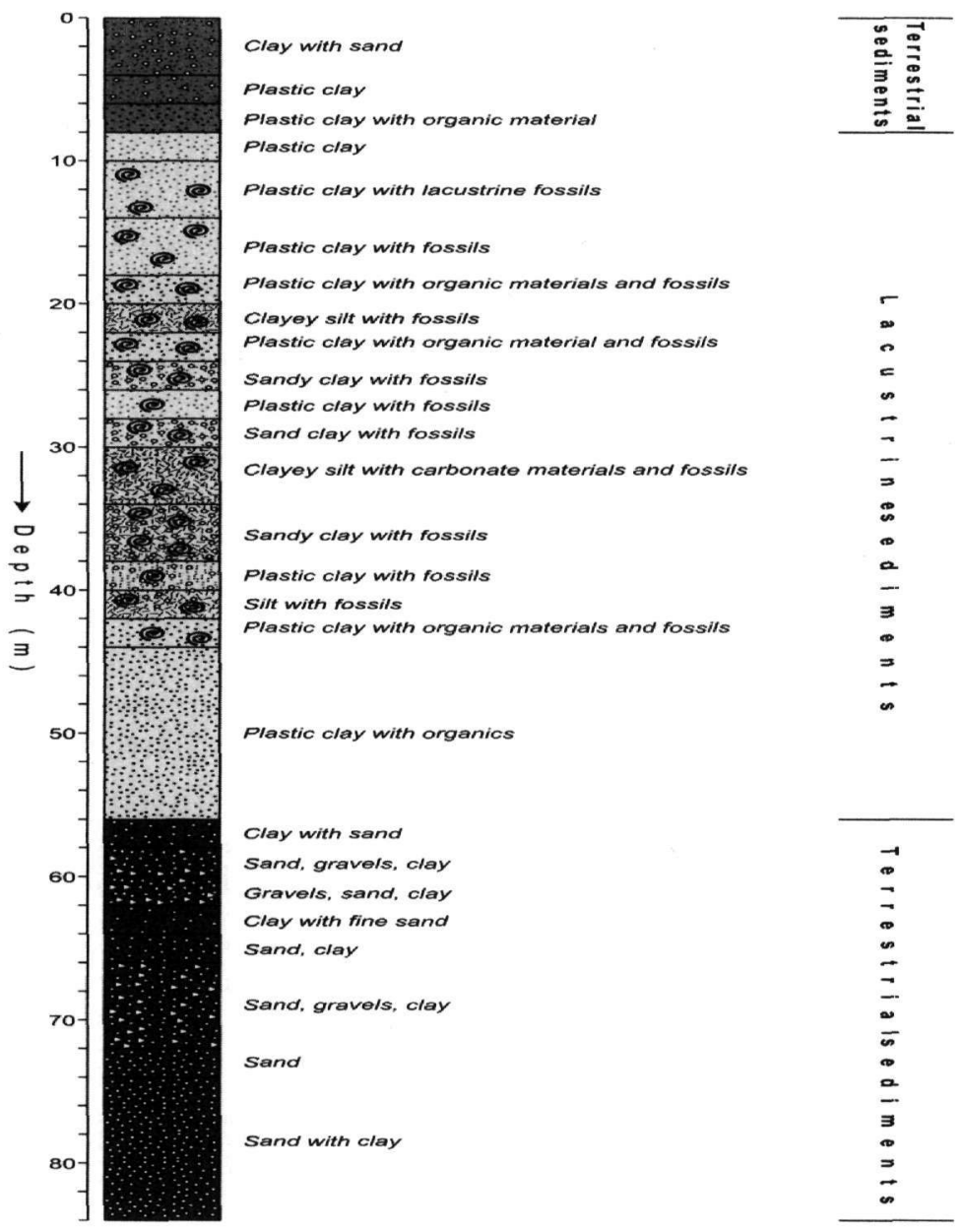

Figure 2 - Geological profile of borehole B1

Time

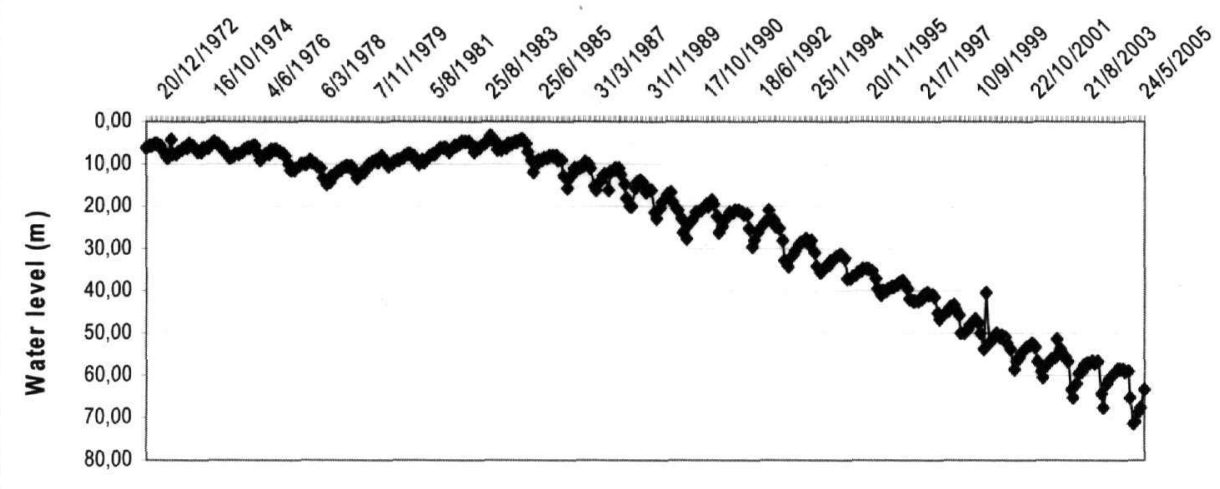

Figure 3 - Hydrograph of groundwater table fluctuations ( $m$ from the ground surface) in a representative borehole of the study area during the period 1972-2003 


\section{Artificial recharge tests}

\subsection{Drilling and pumping test}

One new borehole was drilled (B1), $3 \mathrm{~km}$ North from the village of Chalki. The location is shown in Fig. 1. The selection of the location was made by using criteria like availability of land, high permeability, water availability to recharge, etc. After borehole had been drilled, pumping test (constant discharge 24-h) was carried out, in order to estimate the hydraulic parameters. The pumped discharge of the borehole was measured to be $26 \mathrm{~m}^{3} / \mathrm{h}$. The groundwater level was encountered at an average depth of $19.5 \mathrm{~m}$ below the ground surface. Furthermore, one piezometer (P1) was drilled at a short distance $(\sim 18 \mathrm{~m})$ from the borehole B1.

Transmissivity (T), Storativity (S) and hydraulic conductivity (k) were calculated using the Cooper-Jacob method (Jacob, 1946, Batu, 1998). The mean coefficient of Transmissivity is $3.1 \times 10^{-3} \mathrm{~m}^{2} / \mathrm{s}$ and the hydraulic conductivity $\mathrm{k}=2.6 \times 10^{-5} \mathrm{~m} / \mathrm{s}$. Storage coefficient is $10^{-2}$.

\subsection{Recharge water injection system}

Water from another pumping borehole (at distance of $500 \mathrm{~m}$ ), without any treatment, was used during the artificial recharge experiment in the borehole B1 (Fig. 4). Measurements of groundwater level were made in the piezometer of the recharge borehole and the piezometer P1 at distance of $17.85 \mathrm{~m}$ from the borehole $\mathrm{B} 1$.

The quality of the recharge and existing water is shown in Table 1 . The differences could be associatedwith the different depths of boreholes. The $\mathrm{Mg}-\mathrm{HCO}_{3}$ is the dominant water type.

The duration of the recharge experiment was relatively short ( 7 days). The recharge flow rate was initially $20 \mathrm{~m}^{3} / \mathrm{h}$ for 4 days and then it was increased at $30 \mathrm{~m}^{3} / \mathrm{h}$ until the end of the experiment. The total volume of recharge water in the boreholes was $4,080 \mathrm{~m}^{3}$. After the end of the recharge experiment, water level measurements were taken place for another 8 days.

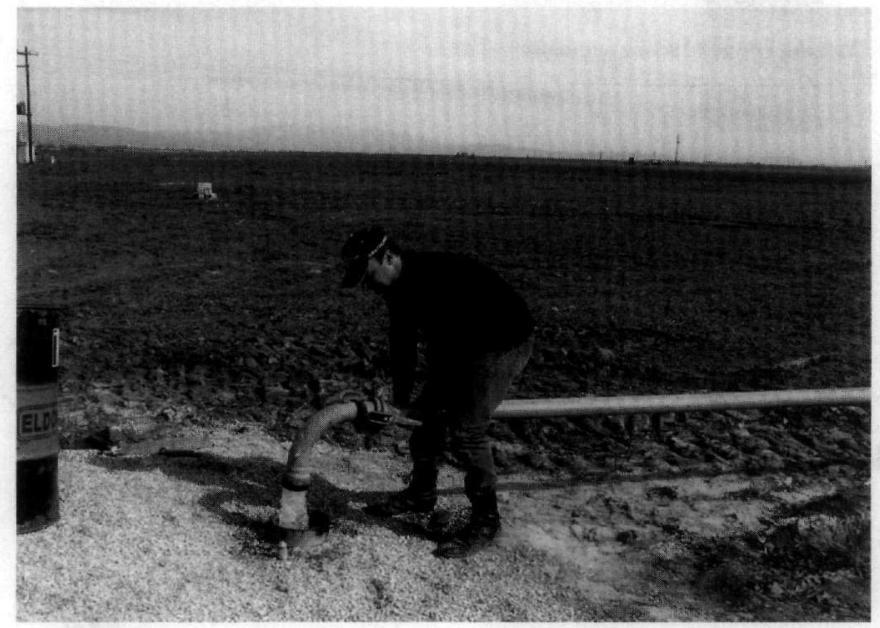

Figure 4-Water recharge injection system

\subsection{Artificial recharge through trench}

The trench is located close to the railway and has a length of $110 \mathrm{~m}$ (Fig. 5). Water from the neighbouring torrent, without any treatment, was used. Measurements of groundwater level were made in the piezometer at a distance of $15 \mathrm{~m}$ from the trench (Fig. 6). The quality of the recharge water is shown in Table 1. 
Table 1- Chemical analyses (mg/L) of water

\begin{tabular}{|c|c|c|c|c|c|c|c|c|c|c|}
\hline & $\mathbf{p H}$ & $\begin{array}{c}\mathbf{E . C} . \\
(\boldsymbol{\mu S} / \mathbf{c m})\end{array}$ & $\mathbf{C a}$ & $\mathbf{M g}$ & $\mathbf{N a}$ & $\mathbf{K}$ & $\mathbf{H C O}_{3}$ & $\mathbf{C l}$ & $\mathbf{S O}_{4}$ & $\mathbf{N O}_{3}$ \\
\hline $\begin{array}{c}\text { Existing water } \\
\text { in borehole B1 }\end{array}$ & 7.80 & 809 & 19 & 68.7 & 55 & 1.4 & 326 & 14 & 112 & 4.4 \\
\hline \begin{tabular}{c} 
Recharge water \\
\hline $\begin{array}{c}\text { Recharge water } \\
\text { in trench }\end{array}$
\end{tabular} & 7.86 & 632 & 16.8 & 32.4 & 72 & 1.3 & 241 & 12 & 86 & 17.6 \\
\hline
\end{tabular}

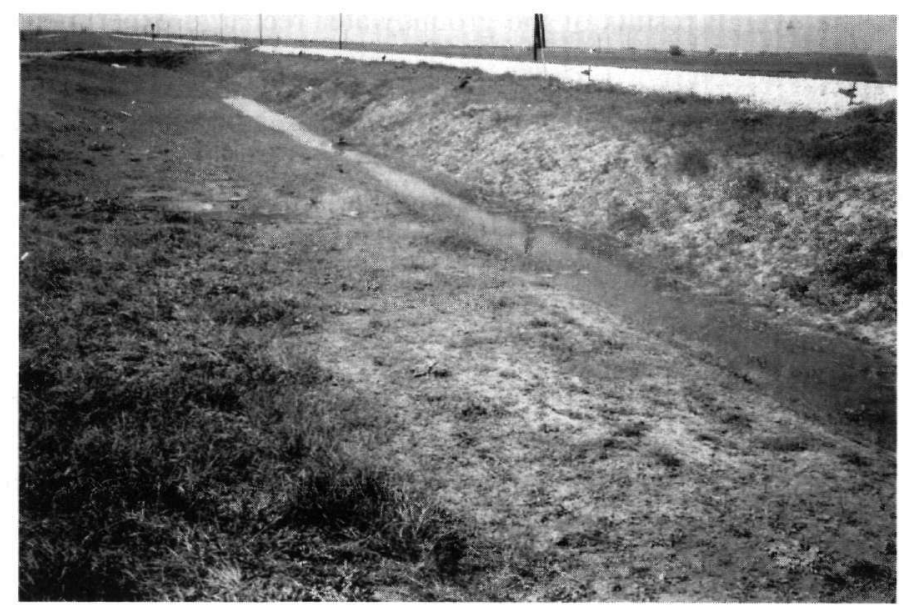

Figure 5-Water recharge system through trench

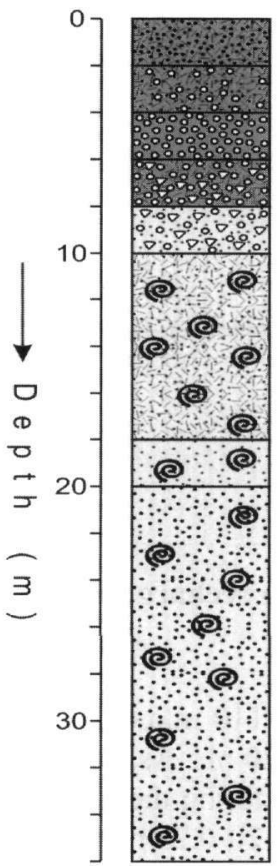

Clay, silty-clay

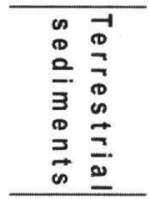

Plastic clay, gravels, sand

Silty clay with fossils

Clay, silt, sand

Sand

Sand, gravels, silt

$\overrightarrow{0} \overline{0}$

Plastic clay, gravels, sand

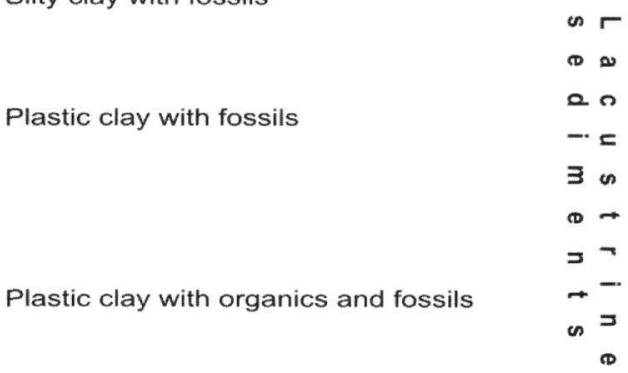

Figure 6-Geological profile of piezometer P2 
The duration of the recharge experiment was 7 days. The recharge flow rate was initially $45 \mathrm{~m}^{3} / \mathrm{h}$ for 6 days and the last day it was $60 \mathrm{~m}^{3} / \mathrm{h}$ until the end of the experiment. The total volume of recharge water in the trench was $7,920 \mathrm{~m}^{3}$. Water level measurements were taken place during the experiment and for 10 days after the end of the experiment.

\section{Results}

\subsection{Water recharge via borehole}

The rise of the groundwater level at the end of the experiment in the borehole $\mathrm{B} 1$ ranges between $3.5 \mathrm{~m}$ in piezometer $\mathrm{P} 1$ and $5.5 \mathrm{~m}$ in borehole $\mathrm{B} 1$, assuming that the water level due to natural recharge was negligible. The groundwater level rise was decreasing with the distance from recharge borehole. The overall results of the groundwater recharge experiments are presented in Table 2.

Figure 7 shows the fluctuation of the water level in the recharge borehole B1 and in the piezometer $\mathrm{P} 1$ at distance $17.85 \mathrm{~m}$, during the experiment. Figure 8 shows the fluctuation of the water level in the recharge borehole $\mathrm{B} 1$ and in the piezometer $\mathrm{P} 1$ for the time after the end of the experiment.

Transmissivity (T) was calculated to be $3.4 \times 10^{-3} \mathrm{~m}^{2} / \mathrm{s}$, based on the analysis of the data of the recharge. Specific capacity $(\mathrm{Q} / \mathrm{s})$ is defined as the ratio of discharge $(\mathrm{Q})$ to drawdown $(\mathrm{s})$ at the pumping borehole for a given time.

The specific capacity $(\mathrm{Q} / \mathrm{s})$ was estimated to be $3.8 \mathrm{~m}^{3} / \mathrm{h} . \mathrm{m}$ during the pumping test, whereas during the experiment the specific capacity was $7.0 \mathrm{~m}^{3} / \mathrm{h} . \mathrm{m}$. The difference could be associated with the different rates of pumping and recharge $26 \mathrm{~m}^{3} / \mathrm{h}$ and $20 \mathrm{~m}^{3} / \mathrm{h}$, respectively. It is concluded that, under the same water level variations in the borehole $\mathrm{B} 1$, the pumping rate is smaller than the injection rate.

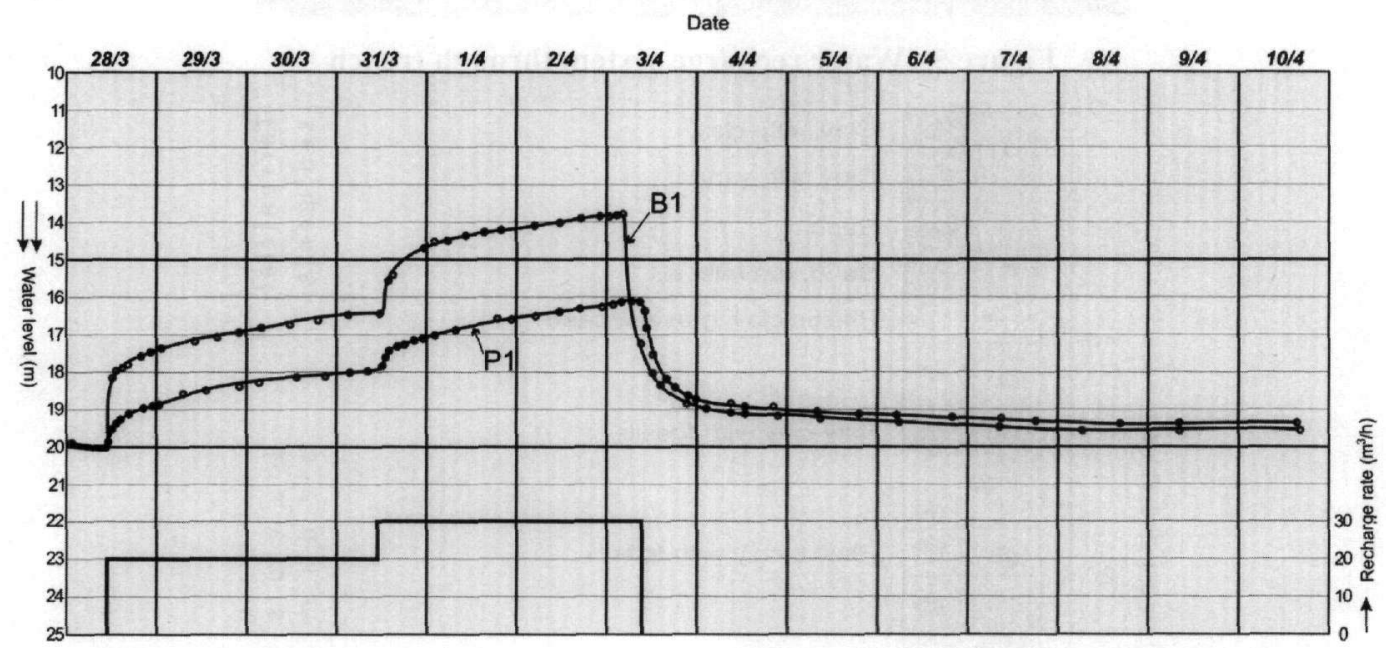

Figure 7-Fluctuation of groundwater level during the recharge in borehole B1

\subsection{Recharge from a trench}

The width of the trench was approximately $2 \mathrm{~m}$ and the length $110 \mathrm{~m}$; consequently the recharge area was $200-220 \mathrm{~m}^{2}$. The depth of recharge water was $0.15-0.20 \mathrm{~m}$. As it is aforementioned, the recharge rate was $45 \mathrm{~m}^{3} / \mathrm{h}$ during the first six days and $60 \mathrm{~m}^{3} / \mathrm{h}$ during the last day. It is concluded that, the rate of water absorption was $0.20-0.25 \mathrm{~m}^{3} / \mathrm{h}$ per $\mathrm{m}^{2}$ or $0.20-0.25 \mathrm{~m} / \mathrm{h}$. 


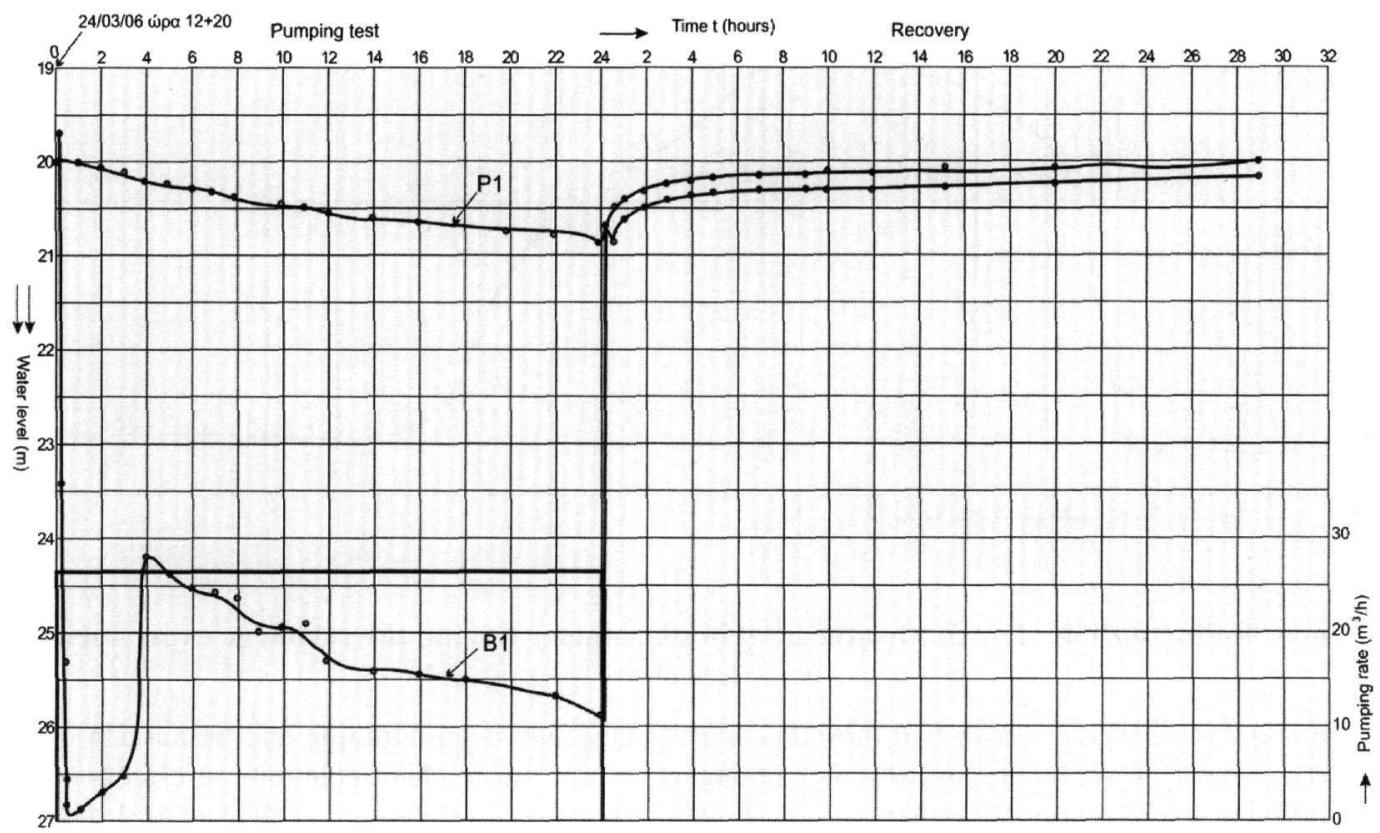

Figure 8 - Fluctuation of groundwater level in borehole B1 and piezometer P1 during the recharge experiment and recovery

Table 2- Results of the recharge experiments

\begin{tabular}{|l|c|c|c|c|}
\hline Recharge method & $\begin{array}{c}\text { Rate } \\
\left(\mathbf{m}^{\mathbf{3}} \mathbf{h}\right)\end{array}$ & $\begin{array}{c}\text { Duration } \\
(\mathbf{d a y s})\end{array}$ & $\begin{array}{c}\text { Total volume } \\
\text { of recharge } \\
\text { water } \\
\left(\mathbf{m}^{\mathbf{3}}\right)\end{array}$ & $\begin{array}{c}\text { Water } \\
\text { level } \\
\text { rise* } \\
(\mathbf{m})\end{array}$ \\
\hline Borehole & 20 and 30 & 7 & 4,080 & 3.78 \\
\hline Trench & 45 and 60 & 7 & 7,920 & 13.0 \\
\hline
\end{tabular}

* In piezometer at distance of 15-18 $\mathrm{m}$ at the end of the experiments

The water level rise in piezometer at a distance of $15 \mathrm{~m}$ is recorder $60 \mathrm{~h}$ after the beginning of the experiment (Fig. 9). The water level stabilized 6 days after the end of the recharge, $0.70 \mathrm{~m}$ higher than the beginning of the experiment.

\section{Conclusions}

Recharge experiments through deep borehole, drilled in alluvial deposits and trench were carried out in Larisa prefecture during the March-April 2006. These experiments aimed at getting insight into the feasibility of recharging aquifers with surface water.

The duration of the recharge experiments was 7 days. The total volume of recharge water in the borehole and trench was $4,080 \mathrm{~m}^{3}$ and $7,920 \mathrm{~m}^{3}$, respectively.

The maximum rise of the groundwater level at the end of the test was $4.5 \mathrm{~m}$ in the injection borehole. This field test showed that, recharge rate was about $20 \mathrm{~m}^{3} / \mathrm{h}$. The water absorption in trench was $0.20-0.25 \mathrm{~m}^{3} / \mathrm{h}$ per $\mathrm{m}^{2}$ or $0.20-0.25 \mathrm{~m} / \mathrm{h}$. 


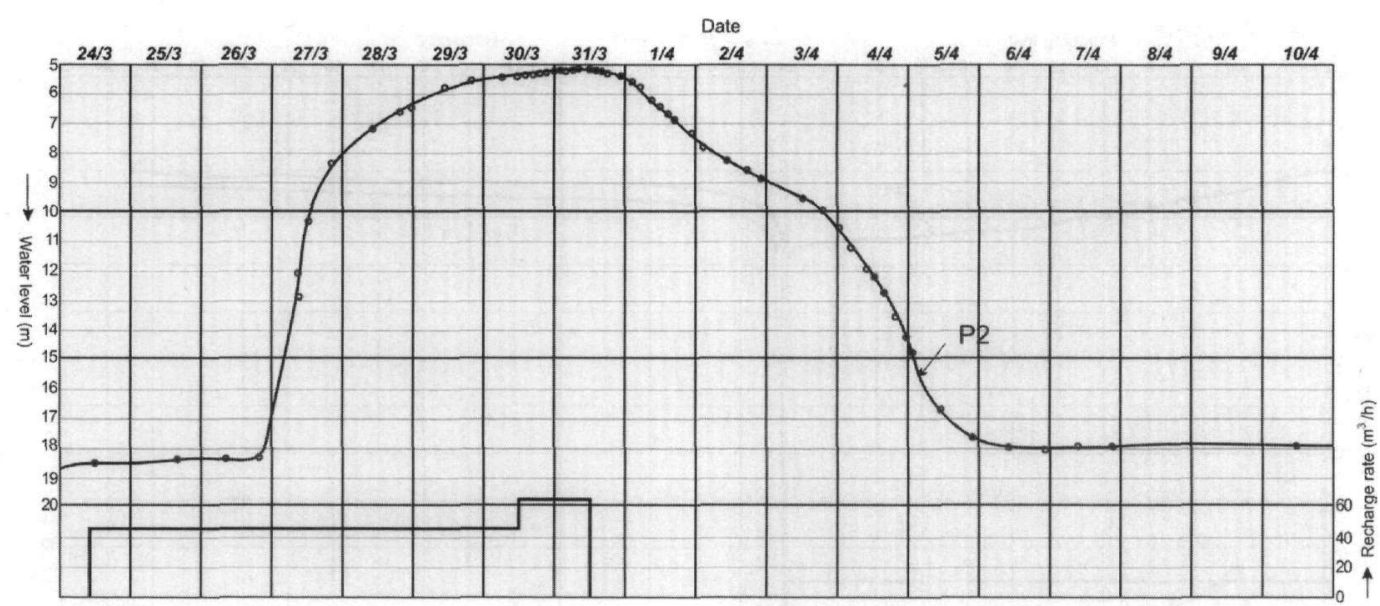

Figure 9-Fluctuation of groundwater level in piezometer during the recharge experiment in trench

Field experiments have shown that, groundwater recharge via deep borehole and trench can be an effective mean of augmentation of water resources in the future. The technique is effective and feasible and may be applied as part of a sustainable water resources management plan, based on surface and groundwater exploitation, simultaneously.

Further analysis is required to assess the longer-term behaviour of the injection borehole and hydraulic parameters of the aquifer. This may involve simulation of groundwater flow and extended field experiments.

\section{Acknowledgements}

This research was supported by the Region of Thessaly.

\section{References}

Batu, V., 1998. Aquifer hydraulics - A comprehensive guide to hydrogeological data analysis, $E d$. John Wiley \&Sons Inc., New York, 727.

Bize, J., Bourguet, L., and Lemoine, J., 1992. L' alimentation artificielle des nappes souterraines, Editions Masson et $C^{i e}$, Paris, 200.

Bouwer, H., 1996. Issues in artificial recharge, Water Sci. Tech., 33(10-11), 381-396.

Buchn, S., 1964. The problem of groundwater recharge. Artificial recharge as a source of water, Inst of water, Engineering Journal, 18(3), 239-246

Diamantis, J., Pliakas, F., and Petalas, C., 1999. Application of artificial recharge in the aquifer atVafeika region (Xanthi), Proc. $5^{\text {th }}$ Conf. on Hydrogeology, Cyprus, 81-96. (in Greek)

Fleet, M., and Voudouris, K., 1995. Experiment of artificial recharge through borehole in Pliopleistocene deposits of Patras industrial area, Proc. $6^{\text {th }}$ Congress of the Hellenic Hydrotechnical Association, 74-83. (in Greek)

Giao, PH, and Nutalaya, P., 1998. Field experiment of artificial recharge through a well with reference to land subsidence control, Engineering Geology, 50, 187-201.

Hionidi, M., Panagopoulos, A., Koumantakis, I., and Voudouris, K., 2001. Groundwater quality considerations related to artificial recharge to the aquifer of the Korinthos Prefecture, 
Greece, Groundwater quality: Natural and enhanced restoration of groundwater pollution, IAHS publication No 275, 85-90.

Jacob, C.E., 1946. Radial flow in a leaky artisian aquifer, Transactions Amer. Geophys. Union, 27, 198-205.

Katsikatsos, G., Vidakis, M., and Migiros, G., 1977. Geological map of Greece, 1:50000, Platykampos sheet. Editions IGME.

Koumantakis, J., Panagopoulos, A, Stavropoulos, X., and Voudouris, K., 1999. Application of aquifer artificial recharge in the coastal alluvial basin of the northern part of Korinthos Prefecture, Peloponnesus,. Proc. $5^{\text {th }}$ Conf. on Hydrogeology, Cyprus, 65-80. (in Greek)

Murray, EC., and Tredoux, G., 2002. Karkams borehole injection tests: Results from injection into a low-permeability fractured granitic aquifer, Proc. of the $4^{\text {th }}$ Intern. Symposium on Artificial Recharge of groundwater. Adelaide, Australia, 301-304.

Peters, JH., 1985. Borehole recharge in water supply. Hydrogeology in the service of man, Memoires of the $18^{\text {th }}$ congress of the LAH, Cambridge.

Poulovasilis, A., et al., 2002. Application of artificial recharge in Argos plain. Recent results and perspectives, Proc. $6^{\text {th }}$ Conf. on Hydrogeology, Xanthi, 59-70. (in Greek)

Soulios, G., 2004. General Hydrogeology, $3^{\text {rd }}$ vol., Kyriakidis ed., 250. (in Greek)

Stavropoulos, X., and Voudouris, K., 2005. Groundwater recharge: Results from deep injection tests in Achaia aquifer systems, SW Greece, Proc. $5^{\text {th }}$ International Symposium on Management of Aquifer Recharge. Berlin, Germany. (in press)

Vafiadis, P., and Panoras, A., 1996. Study of artificial recharge in the area of Rizo, Petrea, Arsenio, (Pella Perfecture), Editions of National Agriculture Research Foundation, 92. (in Greek)

Voudouris, K., Diamantopoulou, P., Giannatos, G., and Zannis, P., 2006. Groundwater recharge via deep boreholes in Patras Industrial Area aquifer system (NW Peloponnesus, Greece), Bulletin of Engineering Geology and the Environment, 65(3), 297-308. 